\title{
Land-use elements and attributed ecosystem services: an archetype approach to land-use evaluation at the German North Sea coast
}

\author{
Leena Karrasch $^{1,2}$ Thomas Klenke $^{3}$ and Michael Klever ${ }^{4}$
}

\begin{abstract}
The ecosystem services concept has been introduced as a decisive approach to include ecosystem functioning in land-use planning and stakeholder-driven sustainable development. Early integration of stakeholders in participatory processes in the nexus of ecosystem services, climate adaption, and land-use management is still a demanding challenge. This investigation followed a cognitive approach to archetype analysis. We defined cognitive archetypes as recurrent patterns in individual perceptions of social-ecological relations. Our aim was to identify cognitive archetypes based on stakeholders' perceived relation between land-use elements and ecosystem services as exemplified in a German North Sea coastal region. Land-use elements were spatially explicit and delivered a variety of different ecosystem services. The stakeholders were regional decision makers and experts who represented key societal sectors, i.e., water management, agriculture, nature conservation, regional policy, and tourism. Within a participatory process, these stakeholders individually evaluated a matrix of 19 land-use elements and 18 ecosystem services. In terms of archetype analysis, the stakeholders were considered as different cases, and the evaluation of relationships between land-use elements and ecosystem services built the attributions to identify archetypes. They independently agreed on the relevance of close to one-third of 342 attributions, whereas there was disagreement on approximately two-thirds of the possible attributions. By identifying agreements across different sectors, 2 archetypes in land-use element-ecosystem service attributions were identified. The first archetype built on monofunctional attributions, i.e., one land-use element was relevant for the provision of one ecosystem service. The second archetype described land-use elements attributed to bundles of ecosystem services, indicating multifunctionality of land-use elements. Disagreement can result primarily from sector or individual viewpoints. In the case of disagreements, land-use-ecosystem relationships can reveal archetypical mutually exclusive interests, the third archetype. We found that disagreements were mainly individual and not sector specific. This indicated that individual knowledge on service outputs of multiple land uses differed strongly among the stakeholders, particularly with respect to regulatory services.
\end{abstract}

Key Words: archetype approach; ecosystem-based management; ecosystem services; land-use management; stakeholder participation

\section{INTRODUCTION}

The ecosystem services concept is an established approach for linking ecosystems to human well-being. There is increasing interest that this concept should be part of land-use management and spatial planning processes (Fürst et al. 2017). With regard to land use, numerous and sometimes competing services result from multiple interactions between humans and the environment. The understanding, recognition, and spatial distribution of ecosystem services provided by landscapes are of critical relevance for adaptive land-use management (de Groot et al. 2010, Müller et al. 2010, Koschke et al. 2012, Opdam 2013, Potschin and HainesYoung 2013, Vrebos et al. 2015). Climate adaptation strategies can profit from ecosystem-based management approaches, with an emphasis on stakeholder participation and operationalization of the concept of ecosystem services (Schultz et al. 2015). However, early integration and implementation of ecosystem services into ecosystem-based management and planning processes remains a challenge (Daily and Matson 2008, Fish 2011, Müller and Burkhard 2012, Albert et al. 2014, Schleyer et al. 2015, Fürst et al. 2017). Therefore, approaches are needed to quantify the relationships between land-use elements and ecosystem services (de Groot et al. 2010, Potschin and Haines-Young 2013).

Land-use elements can be understood as delineable spatial patches, both ecological, like grasslands or salt marshes, and anthropogenic, such as road infrastructure or buildings. Connecting ecosystem service delivery with land-use and landcover elements has several advantages. First, land-use elements can be understood as spatial representations of ecosystems, particularly in the highly patterned cultural landscapes of northwestern Europe. Second, land-use elements often provide bundles of several services generating either synergies or tradeoffs. Third, a wealth of information is available on service outputs at the habitat scale, such as biodiversity or agricultural data (Potschin and Haines-Young 2013). Several attempts have been made to determine the capacity of land cover, habitats, or places to deliver ecosystem services, resulting in the provision of valuable frameworks based on researchers' knowledge and scientific literature surveys. However, participatory approaches that include local land users and other stakeholders are often lacking (Burkhard et al. 2009, UK National Assessment 2011, Koschke et al. 2012, Potschin and Haines-Young 2013, Verhagen et al. 2016, 2018, Lavorel et al. 2017, Stürck and Verburg 2017).

Ecosystem service outputs of land-use elements are often assessed by ecologists and based on measurable indicators such as crop yield, methane emission, or transpired water (i.e., CebriánPiqueras et al. 2017b, Langerwisch et al. 2018). However, measurements of productivity, nutrient and water fluxes, and other ecosystem functions and properties can hardly be done for all land-use elements of a regional administrative unit such as a county. This regional scale is, however, the focus of land-use allocation and planning. Regional administrations are often the main addressee for ecosystem service assessments in practical landscape planning (Rauken et al. 2015, Wamsler 2015). An alternative pathway to develop county-wide assessments of a

${ }^{1}$ Ecological Economics, University of Oldenburg, ${ }^{2}$ COAST-Centre for Environmental and Sustainability Research, University of Oldenburg, ${ }^{3}$ COAST-Centre for Environmental and Sustainability Research, University of Oldenburg, ${ }^{4}$ Landscape Ecology Group, Institute of Biology and Environmental Sciences, University of Oldenburg 
broad range of land-use elements is to ask regional stakeholders to evaluate ecosystem service outputs of land-use elements, based on their local knowledge, familiarity with the landscape, and social context (Cebrián-Piqueras et al. 2017b). This approach would include the cognitive dimension in the assessment, i.e., the contribution of stakeholders and beneficiaries to the quantification of ecosystem service outputs or the consideration of societal demands in land management and decision-making processes (Dunford et al. 2018). A participatory evaluation is based on the individual perception of stakeholders, rather than on measured ecosystem functions and properties (Karrasch et al. 2017).

An important question regarding stakeholder assessments is whether stakeholders from different societal sectors agree on their evaluation of ecosystem service outputs. If so, the land-use element-ecosystem service evaluations are recurrent across different societal sectors and could be seen as archetypical from a cognitive perspective. In the context of sustainable land management, archetypes are often understood as recurrent representations of land-use systems linking environmental conditions to demands of the social system (Václavík et al. 2013, Sietz et al. 2017, Levers et al. 2018). The concept of archetypes constitutes a methodological approach to understand such recurrent patterns together with processes and conditions that shape managed systems, i.e., with respect to climate change adaptation and regional development (Oberlack and Eisenack 2014, Oberlack et al. 2016, Wardropper et al. 2016). Archetypes "illustrate basic underlying processes and are made to draw connections between regions and to assist decision-makers recognizing their particular situation within a broad context" (Eisenack 2012:109). Archetype identification and analysis can be applied at different scales, ranging from global (Václavík et al. 2013) and landscape (Cullum et al. 2017) to household levels (Sietz et al. 2012). With respect to participatory processes, archetypes defining patterns of societies' vulnerability and risk perceptions have been developed using mixed-method approaches including qualitative and quantitative data and analyses (e.g., LimCamacho et al. 2017, Vidal Merino et al. 2018).

We ask how stakeholders perceive and evaluate the relationships between land-use elements and ecosystem services. Complementing archetype analyses based on, e.g., modeling and statistical analyses of functional relations of social-ecological systems (e.g., Václavík et al. 2013, Cullum et al. 2017, Sietz et al. 2017), this investigation identifies archetypes based on stakeholders' perceptions, including their evaluation of the environment.

Therefore, we define cognitive archetypes as recurrent patterns in individual perceptions of social-ecological relations. The identification of cognitive archetypes in relation to land-use elements and ecosystem services intends to link land use (subjective dynamics, demand side) with ecosystem functioning and provision of services (objective dynamics, supply side). Even though stakeholders' interests, perceptions, and evaluations can be regarded as nondeterministic and self-reflexive, they are an important instrument to couple social and ecological systems and promote sustainable development (Manuel-Navarrete 2015).

This investigation is designed to identify cognitive archetypes that are determined by two different characteristics. The first is archetypes that are independent from sectoral interests and perspectives. These archetypes are described by a set of attributions that find cross-sectoral agreement. The second is archetypes that build the basis for further discussions in a participatory process, as a result of attributions that are based on individual perceptions. The archetype analysis contributes to determining building blocks for designing climate adaptive and ecosystem-based land-use management in future steps.

\section{MATERIAL AND METHODS}

\section{Case study region}

We selected a case study region strongly modified by human land use. The community of Krummhörn (159 km², 12,300 inhabitants) is located in a low-lying coastal area in the German North Sea region at the Ems-Dollart estuary (Fig. 1). After centuries of land reclamation (Reise 2005), today about one-third of the total area is below sea level and vulnerable to impacts of climate change, such as increasing precipitation and sea level rise. Intensively used agricultural fields and grasslands, combined with networks of canals and ditches, as well as historical settlements on artificial mounds, characterize the landscape of Krummhörn. To deal with these increasing pressures and ensure sustainable land-use management in the future, alternative courses of action are needed (Karrasch et al. 2017). An archetype analysis is expected to support this process.

Flooding of the marsh in earlier periods deposited highly productive soils. Therefore, the old marsh areas provide good conditions for grassland and are used for dairy farming and the production of forage. The areas of young marsh, with fertile clay soils, provide good conditions for arable farming. Without the sea dike that protects the community from North Sea floods and a sophisticated drainage system in the hinterland, no land use would be possible in this low-lying coastal area. Besides agricultural activities ( $75 \%$ of Krummhörn is used for agricultural production), tourism is a vital and increasing source of income, especially during the summertime. The flat and open landscape, together with historical settlements, enhances the recreational value of the region. Furthermore, the entire region has very high natural potential: in addition to being a Wadden Sea World Heritage Site (dike foreland), about $40 \%$ of the mainland has been designated under the European Union (EU) directive on the conservation of wild birds (European Parliament, Council of the European Union 2010) and the EU directive on the conservation of natural habitats (Council of the European Union 1992).

\section{Cognitive archetype analysis}

According to Eisenack et al. (2018), archetype analyses encompass two phases, the elicitation and the diagnosis phases. This investigation addresses the elicitation phase, which includes selection of cases and identification of archetypes. Each stakeholder was considered as a single case and evaluated attributions of land-use elements and ecosystem services according to his or her own perceptions. To define a suite of archetypes, the cases with their attributes were analyzed and compared. The resulting cross-sectoral evaluation patterns provided the foundation for subsequent identification of cognitive archetypes.

In the second phase of archetype analysis (diagnosis phase, not our scope), these archetypes can be used as building blocks to develop ecosystem-based and climate adaptive land management options for further planning processes (Fig. 2). 
Fig. 1. Location of the community of Krummhörn in northwestern Germany $\left(53^{\circ} 26^{\prime} \mathrm{N}, 7^{\circ}\right.$ $03^{\prime} \mathrm{E}$ ). The case study area measures $159 \mathrm{~km}^{2}$ in total, including approximately $6.5 \mathrm{~km}^{2}$ of settlements; $60 \mathrm{~km}^{2}$ of grassland, including meadows and pastures, intensively and extensively used grassland, and extensively used wetland; $72 \mathrm{~km}^{2}$ of arable land and fields; and $362 \mathrm{~km}$ of drainage system, i.e., rivers, creeks, and ditches. Asterisk indicates a potential future land cover and use could be the development of polder areas $\left(2.1 \mathrm{~km}^{2}\right)$ to store freshwater in times of extreme precipitation or promote peat formation.

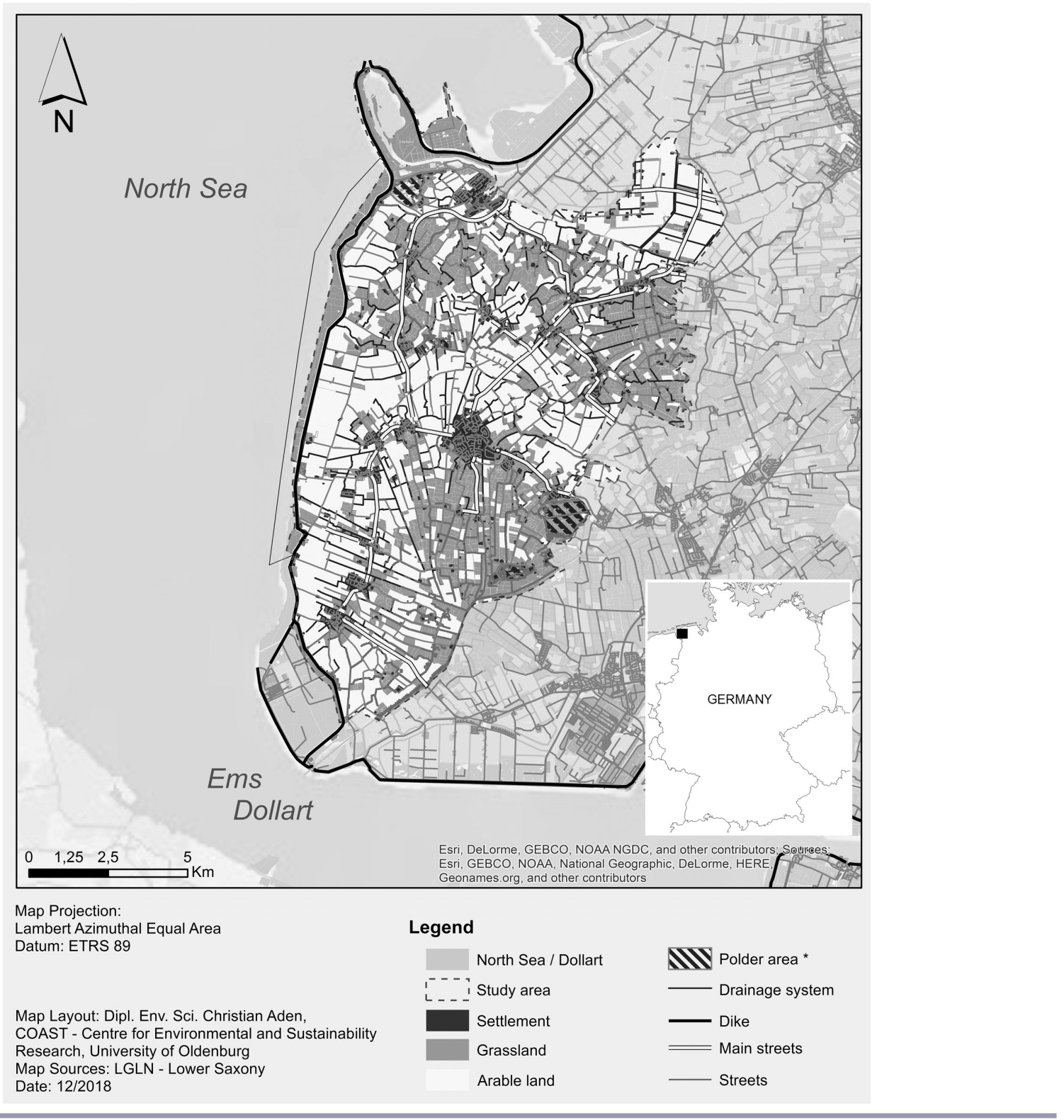

\section{Participatory evaluation of land-use element-ecosystem service attributions}

Twelve stakeholders were consulted within the participatory process of data acquisition. These stakeholders were selected because they have decision-making powers, cover all different land-use interests, and provide specific and extensive knowledge on different kinds of land use in both theory and practice in the case study region. They are experts and decision makers who represent the interests of their specific sector in the fields of water management $(n=3)$, agriculture $(n=3)$, nature conservation $(n$ $=2)$, policy $(n=3)$, and tourism $(n=1$; Table 1$)$.

With each of these stakeholders, we compiled evaluations of landuse element-ecosystem service attributions. This process required guidance by the researchers to facilitate the understanding of the ecosystem service approach, because most stakeholders were not familiar with the concept (Karrasch 2016). The whole procedure 
Fig. 2. Cognitive archetype analysis (see Eisenack 2012, Eisenack et al. 2018).

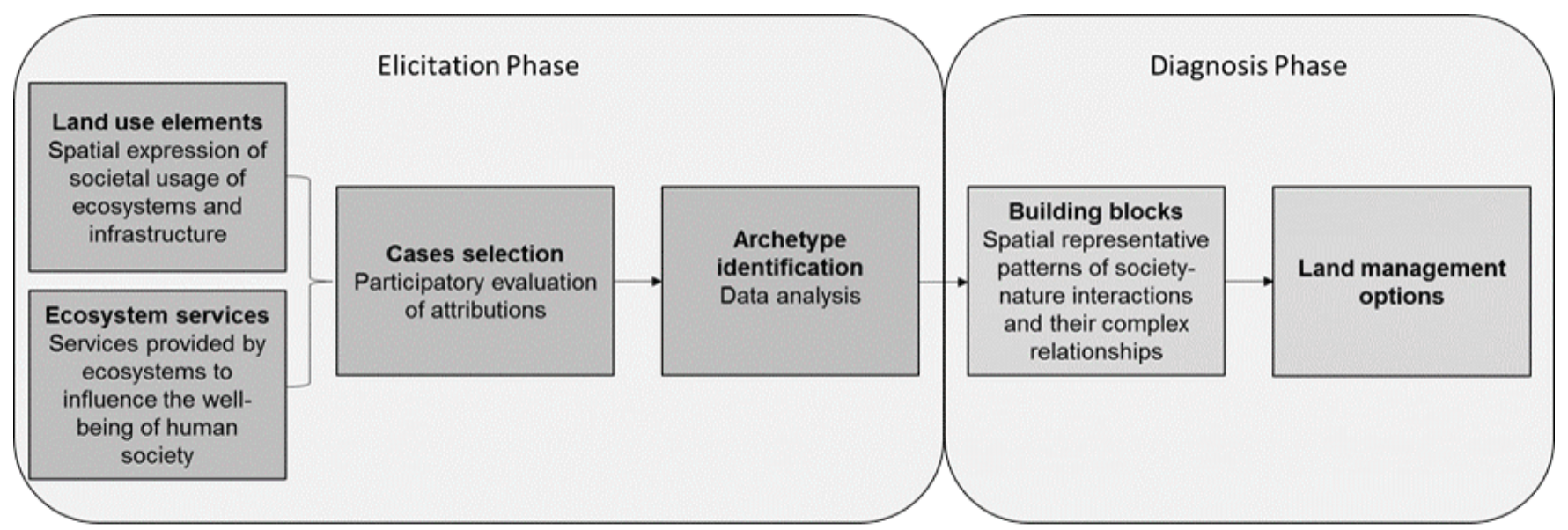

Table 1. Sectors, institutions, levels, and interests of the 12 stakeholders included in the participatory process.

\begin{tabular}{|c|c|c|c|}
\hline Sector & Stakeholder's Institution & Level & Interests \\
\hline \multirow[t]{3}{*}{ Water management } & Water Board Emden & $\begin{array}{l}\text { Engineer, autonomous public corporation } \\
\text { (local) }\end{array}$ & $\begin{array}{l}\text { Maintenance of second- and third-order } \\
\text { waters, regulation of water levels }\end{array}$ \\
\hline & Water Board Emden & $\begin{array}{l}\text { Director, autonomous public corporation } \\
\text { (local) }\end{array}$ & $\begin{array}{l}\text { Management of the district of the Water } \\
\text { Board Emden }\end{array}$ \\
\hline & Dike Board Krummhörn & $\begin{array}{l}\text { Director, autonomous public corporation } \\
\text { (local) }\end{array}$ & $\begin{array}{l}\text { Responsible for maintenance of dikes, } \\
\text { associated constructions, and dike } \\
\text { foreland, as well as disaster control }\end{array}$ \\
\hline \multirow[t]{2}{*}{ Nature conservation } & National Park of Lower Saxony & $\begin{array}{l}\text { Head of department, state authority } \\
\text { (regional) }\end{array}$ & $\begin{array}{l}\text { National park administration, nature } \\
\text { protection }\end{array}$ \\
\hline & $\begin{array}{l}\text { National Park and Biosphere } \\
\text { Reserve of Lower Saxony }\end{array}$ & $\begin{array}{l}\text { Head of department, state authority } \\
\text { (regional) }\end{array}$ & $\begin{array}{l}\text { Biosphere reserve administration, } \\
\text { sustainable development, interactions } \\
\text { between natural and social processes }\end{array}$ \\
\hline \multirow[t]{3}{*}{ Agriculture } & Farmers' Association East Frisia & $\begin{array}{l}\text { Director, registered association (local, } \\
\text { regional) }\end{array}$ & $\begin{array}{l}\text { Agricultural and rural development, lobby } \\
\text { for agricultural interests }\end{array}$ \\
\hline & Farmers' Association East Frisia & Farmer and board member (local) & $\begin{array}{l}\text { Practitioner, lobby for agricultural } \\
\text { interests }\end{array}$ \\
\hline & $\begin{array}{l}\text { Chamber of Agriculture Lower } \\
\text { Saxony }\end{array}$ & $\begin{array}{l}\text { Head of department, autonomous public } \\
\text { corporation (regional) }\end{array}$ & $\begin{array}{l}\text { Land-use planning and rural development } \\
\text { department, lobby for agricultural } \\
\text { interests }\end{array}$ \\
\hline \multirow[t]{3}{*}{ Policy } & Community of Krummhörn & Mayor, state authority (local, regional) & Representative of the community \\
\hline & County of Aurich & $\begin{array}{l}\text { Head of department, public authority } \\
\text { (regional) }\end{array}$ & $\begin{array}{l}\text { Regional and land-use planning, } \\
\text { coordination of interests }\end{array}$ \\
\hline & $\begin{array}{l}\text { Administrative office for rural } \\
\text { development }\end{array}$ & $\begin{array}{l}\text { Head of department, state authority } \\
\text { (regional) }\end{array}$ & State property administration \\
\hline Tourism & Tourism Association in East Frisia & $\begin{array}{l}\text { Director, independent limited liability } \\
\text { company (local, regional) }\end{array}$ & $\begin{array}{l}\text { Development of tourism infrastructure } \\
\text { and marketing }\end{array}$ \\
\hline
\end{tabular}

in this investigation included 4 different sessions with each stakeholder over a period of 1 year.

1. Examination and definition of existing land-use elements. A list of land-use elements that might potentially occur in the area according to the CORINE Land Cover classes (Bossard et al. 2000) was presented to each stakeholder. Semistructured interviews were used to select and define 19 land-use elements present in the case study area.

2. Agreement on ecosystem services relevant for the study area. A list with preselected ecosystem services according to the
Millennium Ecosystem Assessment (2003) was presented to each stakeholder. In semistructured interview sessions, the stakeholders selected and defined 18 ecosystem services they considered relevant to the case study region.

3. The results of the semistructured interviews were used to write a glossary explaining the meaning of each land-use element and ecosystem service from the stakeholders' perspectives. This glossary was discussed in sector-specific focus group meetings to ensure that all relevant and regionalspecific aspects were included. 
4. Quantitative assessment of attributions. The final selection of 19 land-use elements and 18 ecosystem services was arranged in a table with land-use elements as rows and ecosystem services as columns. It was the stakeholders' task to evaluate 342 attributions by answering the question: How important is a certain land-use element for the provision of a certain ecosystem service? To avoid misunderstandings, the glossary of definitions was used during the evaluation process. Each of the 12 stakeholders evaluated the relevance of each land-use element for the provision of a certain ecosystem service with either no relevance (1), medium relevance (2), or high relevance (3), resulting in an ordered list of 12 numbers ranging from 1 to 3 .

\section{Data analysis}

Across all 12 cases of 342 attributions, we compared and analyzed the number of attributions with agreement, with disagreement, and with contrary opinion, using the Simpson's index, the variance, and the median.

The Simpson's index ( $D$; Eq. 1) was used to determine the agreements (homogeneity in evaluations), as well as disagreements and contrary opinions (heterogeneity of evaluations), for each attribution in relation to the 12 cases. The Simpson's index (Simpson 1949) measures the probability that 2 evaluations for the same attribution randomly taken from the 12 cases are equal.

$$
D=\frac{\sum n_{i}\left(n_{i}-1\right)}{N(N-1)}
$$

In Eq. $1, n$ is the number of evaluation $i$, and $N$ is the total number of the evaluations. In our investigation, the value of $D$ ranges between 0.27 and 1 . The higher the value of $D$, the higher is the agreement (homogeneity of evaluations).

A high Simpson's index determines the degree of agreement, but it does not indicate if the 12 stakeholders agreed on either no relevance (1), medium relevance (2), or high relevance (3). This was assessed using the median $\tilde{x}$, i.e., the mean of the 2 middle values in the list of 12 evaluations for each combination of a landuse element and an ecosystem service (Eq. 2).

$$
\tilde{x}=\left(\frac{1}{2} x_{\frac{N}{2}}+x_{\frac{N}{2}+1}\right)
$$

In Eq. 2, $N$ denotes the total number of evaluations.

The variance ( $v$; Eq. 3$)$ is used to distinguish between disagreement and contrary opinions. It measures the dispersion from the arithmetical mean within a particular attribution.

$$
v=\frac{\sum(x-\bar{x})^{2}}{(N-1)}
$$

In Eq. 3, $x$ is the evaluation, $\bar{x}$ is the deviation from the mean, and $N$ is the total number of evaluations. In our investigation, the variance ranges between 0 and 1.1. The higher the value of $v$, the higher the range between evaluations indicating contrary opinions. Disagreement describes mixed stakeholders' evaluations (e.g., 111222223333), whereas contrary opinions are divided between no relevance and high relevance (e.g., 111111333333).

The combination of Simpson's index and median refers to the distribution of the stakeholders' agreements concerning the perceived relevance of attributions. In combination with the variance, three clusters or relevance categories can be distinguished: agreement, disagreement, and contrary opinion. Agreements include three different types depending on the individual grading: agreements concerning no relevance, medium relevance, and high relevance of land-use element/ecosystem service attributions (Table 2). In our investigation, attributions with "high relevance" are used for the identification of archetypes 1 and 2 .

\begin{tabular}{|c|c|}
\hline Cluster & Specification \\
\hline $\begin{array}{l}\text { Agreement: } \\
\text { no relevance }\end{array}$ & $\begin{array}{l}\text { A minimum of } 75 \% \text { evaluated attributions of land-use } \\
\text { element and ecosystem services with } 1 \\
\text { Simpson's index }>0.5 \\
\text { Variance }<75 \% \\
\text { Median value of } 1\end{array}$ \\
\hline $\begin{array}{l}\text { Agreement: } \\
\text { medium } \\
\text { relevance }\end{array}$ & $\begin{array}{l}\text { A minimum of } 75 \% \text { evaluated attributions of land-use } \\
\text { element and ecosystem services with } 2 \\
\text { Simpson's index }>0.5 \\
\text { Variance }<75 \% \\
\text { Median value of } 2\end{array}$ \\
\hline $\begin{array}{l}\text { Agreement: } \\
\text { high relevance }\end{array}$ & $\begin{array}{l}\text { A minimum of } 75 \% \text { evaluated attributions of land-use } \\
\text { element and ecosystem services with } 3 \\
\text { Simpson's index }>0.5 \\
\text { Variance }<75 \% \\
\text { Median value of } 3\end{array}$ \\
\hline Disagreement & $\begin{array}{l}\text { The stakeholders' evaluated attributions of land-use } \\
\text { element and ecosystem services with either } 1,2 \text {, or } 3 \\
\text { Simpson's index }<0.5 \\
\text { Variance }<75 \%\end{array}$ \\
\hline $\begin{array}{l}\text { Contrary } \\
\text { opinions }\end{array}$ & $\begin{array}{l}\text { At least } 40 \% \text { of the stakeholders' evaluated attributions } \\
\text { of land-use element and ecosystem services with } 1 \text {, and } \\
40 \% \text { with } 3 \\
\text { Simpson's index }<0.5 \\
\text { Variance }>75 \%\end{array}$ \\
\hline
\end{tabular}

Table 2. Requirements to cluster the individual stakeholder's evaluations.

Analysis of disagreements

We used nonmetric multidimensional scaling (NMDS) with IBM SPSS Version 25 to analyze whether disagreements and contrary opinions in the attributions show patterns of sector-specific or individual evaluations (archetype 3). NMDS embeds the evaluations of the stakeholders, shows a paired comparison of the cases, and considers inconsistency of ordinal ratings (Agarwal et al. 2007).

\section{RESULTS}

\section{Regional land-use elements and ecosystem services}

The stakeholders agreed on final lists representing their specific regional understanding of land-use elements and ecosystem services (Tables 3 and 4). The process of discussing and defining each land-use element and ecosystem service also raised the stakeholders' understanding and awareness of the diversity of ecosystems and the services they provide. 
Table 3. Final list of regional land-use elements compiled and defined by the stakeholders.

\begin{tabular}{ll}
\hline \hline Land-Use Elements & Definition (According to Stakeholders) \\
\hline Buildings & Areas covered by buildings, for instance settlements, hotels, and industry \\
Infrastructure & Network for transport, for instance roads \\
Recreational sites & Recreational areas and areas used by tourists \\
Dike & Artificial embankment for coastal protection to prevent sea floods \\
Arable fields & Areas used for agriculture, constantly machined surface \\
Meadows and pastures & Areas used for agriculture, constantly machined surface \\
Fields for bioenergy production & Areas used for agriculture, constantly machined surface \\
Intensively used grassland & Areas used for agriculture, mowing, and grazing; up to five cuts per year, high nutrient input \\
Extensively used grassland & Areas used for agriculture, mowing, and grazing; up to two cuts per year, low nutrient input \\
Extensively used wetland & Nature conservation sites or areas that are in use under protected standards; no artificial nutrient input, \\
& one cut per year \\
Rivers, creeks, and ditches & Drainage system of the community \\
Open waters & Natural or artificial open waters \\
Peat areas & Wetlands where depositing of organic material leads to peat formation \\
Reed stands in polder areas & Reed fens in wetlands to yield active peat building and that can be used for economic purposes \\
Polder areas & Freshwater polders to store water \\
Trees & Trees \\
Hedges & Hedges \\
Mudflats & Area between main dike and mean high-water line \\
Salt marshes & Natural areas for coastal protection \\
\hline
\end{tabular}

Table 4. Definitions of regional ecosystem services identified by the stakeholders.

\begin{tabular}{|c|c|c|}
\hline $\begin{array}{l}\text { Ecosystem Service } \\
\text { Class }\end{array}$ & Ecosystem Service & Definition (According to Stakeholders) \\
\hline \multirow[t]{4}{*}{ Provisioning } & Food & Organic material used as food or for food production \\
\hline & Forage & Organic material used for forage production \\
\hline & Energy & Organic material used for biogas generation \\
\hline & Water supply & Storage of freshwater for irrigation and livestock \\
\hline \multirow[t]{11}{*}{$\begin{array}{l}\text { Regulating and } \\
\text { maintenance }\end{array}$} & $\begin{array}{l}\text { Prevention of saltwater } \\
\text { intrusion }\end{array}$ & Prevention of saltwater intrusion in groundwater \\
\hline & Wave attenuation & $\begin{array}{l}\text { Reduction of wave energy and promotion of coastal protection attributable to natural } \\
\text { vegetation structures }\end{array}$ \\
\hline & Rapid water drainage & Regulation of runoff and discharge into the North Sea \\
\hline & Freshwater retention & Water retention areas to store freshwater and buffer flood events \\
\hline & Saltwater retention & Retention areas buffering storm surge or dike overtopping events \\
\hline & Erosion prevention & $\begin{array}{l}\text { Role of vegetation, especially reeds, to avoid sediment erosion attributable to water, wind, or } \\
\text { incorrect management }\end{array}$ \\
\hline & Sedimentation & Soil depositing processes \\
\hline & $\begin{array}{l}\text { Reduction of greenhouse } \\
\text { gases }\end{array}$ & Reduction of greenhouse gases at global and local levels \\
\hline & Carbon sequestration & Reduction of carbon dioxide by reed stands promoting peat building \\
\hline & Biodiversity & Preservation of species and habitat diversity \\
\hline & Soil fertility & $\begin{array}{l}\text { Maintenance of soil quality to keep soils as groundwater filter, store nutrients, and } \\
\text { accumulate organic matter }\end{array}$ \\
\hline \multirow[t]{3}{*}{ Cultural } & $\begin{array}{l}\text { Community identification } \\
\text { and connection }\end{array}$ & $\begin{array}{l}\text { Promotion of regional belonging, willingness to live in the community, traditional relations, } \\
\text { and land-use related to nature }\end{array}$ \\
\hline & Recreation, tourism & Promotion of landscape and biotope features attractive for tourists and locals \\
\hline & Feeling of safety & Absence of fear of being endangered by flood events \\
\hline
\end{tabular}

\section{Cognitive archetype identification: evaluation of land-use element-ecosystem service attributions}

The 12 stakeholders reached agreement in $32.5 \%$ of all attributions (111 attributions). Disagreement scored 65\% (222 attributions), and contrary opinion $2.5 \%$ (9 attributions). Each specific land-use element had a high relevance for at least 1 specific ecosystem service, except extensively used grassland, peat areas, trees, and hedges, respectively (Fig. 3).

Based on the data analyses, we define three cognitive archetypes. Archetypes 1 and 2 present attributions that find agreement among stakeholders from diverse socioeconomic sectors. These archetypes are independent from sectoral interests and perspectives and illustrate the stakeholders' consensus regarding land-use elements and their specific ecosystem service outputs. The third archetype describes mutually exclusive interests and, therefore, disagreements and contrary opinions within the group of stakeholders. This archetype can be used to understand why perceptions differ across cases and delivers a basis for discussion in following participatory processes (Table 5). 
Fig. 3. Archetypes of land-use element-ecosystem service attributions. The different land-use elements are shown in the rows; the columns show provision, regulating, and maintenance, as well as cultural, ecosystem services. The clustering was done according to the stakeholders' evaluation and requirements described in Table 2.

\begin{tabular}{|c|c|c|c|c|c|c|c|c|c|c|c|c|c|c|c|c|c|c|}
\hline \multirow[b]{2}{*}{ Land-Use Elements } & \multicolumn{18}{|c|}{ Ecosystem Services } \\
\hline & $\frac{n}{0}$ & 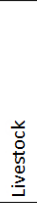 & 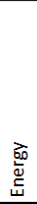 & 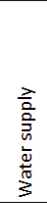 & 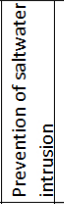 & 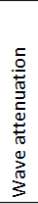 & 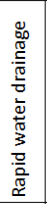 & 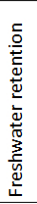 & 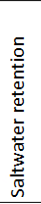 & 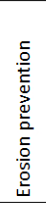 & 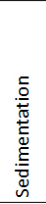 & 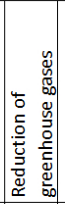 & 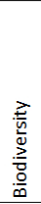 & 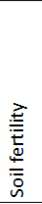 & 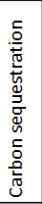 & 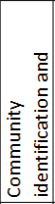 & 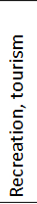 & 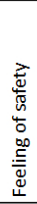 \\
\hline \multicolumn{19}{|l|}{ Fields for bioenergy production } \\
\hline \multicolumn{19}{|l|}{ Extensively used wetlands } \\
\hline \multicolumn{19}{|l|}{ Reed stands in polder areas } \\
\hline \multicolumn{19}{|l|}{ Polder areas } \\
\hline \multicolumn{19}{|l|}{ Dike } \\
\hline \multicolumn{19}{|l|}{ Rivers, creeks, and ditches } \\
\hline \multicolumn{19}{|l|}{ Mudflats } \\
\hline \multicolumn{19}{|l|}{ Salt marshes } \\
\hline \multicolumn{19}{|l|}{ Arable fields } \\
\hline \multicolumn{19}{|l|}{ Meadows and pastures } \\
\hline \multicolumn{19}{|l|}{ Open waters } \\
\hline \multicolumn{19}{|l|}{ Buildings } \\
\hline \multicolumn{19}{|l|}{ Infrastructure } \\
\hline \multicolumn{19}{|l|}{ Recreational areas } \\
\hline \multicolumn{19}{|l|}{ Intensively used grasslands } \\
\hline \multicolumn{19}{|l|}{ Extensively used grasslands } \\
\hline \multicolumn{19}{|l|}{ Peat areas } \\
\hline \multicolumn{19}{|l|}{ Trees } \\
\hline \multicolumn{19}{|l|}{ Hedges } \\
\hline \multicolumn{19}{|l|}{ Evaluation } \\
\hline Agreement: no relevance & & & & Agr & eemen & $\mathrm{t}: \mathrm{m}$ & ediun & rel & van & & & Agre€ & eme & t: hi & 810 & levan & & \\
\hline Disagreement & & & & Con & trary o & & & & & & & & & & & & & \\
\hline
\end{tabular}

\section{Archetype 1: monofunctional attributions}

These archetypical attributions were (1) fields for bioenergy production important for energy generation, (2) reed stands in polder areas facilitating carbon sequestration, (3) extensively used wetlands highly relevant for biodiversity, and (4) polder areas with the principal task of freshwater retention (Fig. 3). Six services proved relevant for only one land-use element: energy as the product of fields for bioenergy production; carbon sequestration by reed stands in polder areas; water supply in relation to open waters; rapid water drainage in relation to rivers, creeks, and ditches; and saltwater retention and sedimentation processes that relate solely to the Wadden Sea mudflats.

\section{Archetype 2: multifunctional attributions}

The second archetype describes land-use elements providing bundles of ecosystem services to fulfill diverse societal, ecological, and economic demands. In particular, the dike was important for the provision of six ecosystem services, i.e. fodder (sheep grazing), prevention of saltwater intrusion, wave attenuation, community identification, recreation and tourism, and the feeling of safety.
Rivers, creeks, and ditches, as well as the dike foreland (mudflats and salt marshes), were considered highly relevant for five different ecosystem services (Fig. 3). Arable fields, meadows, and pastures were evaluated as important for food and fodder provision and soil fertility. Eight land-use elements, for instance buildings, infrastructure, intensively used grassland, open waters, and rivers, were evaluated as highly relevant for the service recreation and tourism. Community identification and the feeling of safety were both linked to four land-use elements, i.e., recreational areas, the dike, mudflats, and salt marshes. The feeling of safety was associated with buildings, infrastructure, and the dike, as well as the salt marshes. Further important ecosystem services with a high degree of agreement were food, forage, freshwater retention, biodiversity, and soil fertility.

Extensively used grasslands, peat areas, trees, and hedges were not evaluated as "highly relevant" for any ecosystem services. These land-use elements are not typical for the case study region and rare and restricted in size in the coastal marshes. 
Table 5. Definitions of cognitive archetypes.

\begin{tabular}{|c|c|c|c|}
\hline Cognitive Archetypes & Definition & Specifics & Example \\
\hline $\begin{array}{l}\text { Archetype } 1 \text { : monofunctional } \\
\text { attributions }\end{array}$ & $\begin{array}{l}\text { One land-use element is highly } \\
\text { relevant for the provision of one } \\
\text { ecosystem service. }\end{array}$ & $\begin{array}{l}\text { All stakeholders agree. Often } \\
\text { self-evident attributions. }\end{array}$ & $\begin{array}{l}\text { Fields used for energy crops are } \\
\text { relevant for energy generation. }\end{array}$ \\
\hline $\begin{array}{l}\text { Archetype 2: multifunctional } \\
\text { attributions }\end{array}$ & $\begin{array}{l}\text { One land-use element is highly } \\
\text { relevant for the provision of } \\
\text { ecosystem services' bundles. }\end{array}$ & $\begin{array}{l}\text { All stakeholders agree. Land-use } \\
\text { elements provide bundles of } \\
\text { ecosystem services to fulfill } \\
\text { diverse societal, ecological, and } \\
\text { economic demands. }\end{array}$ & $\begin{array}{l}\text { Rivers, creeks, and ditches are } \\
\text { important for the provision of rapid } \\
\text { water drainage, freshwater retention, } \\
\text { biodiversity, soil fertility, and } \\
\text { recreation and tourism. }\end{array}$ \\
\hline $\begin{array}{l}\text { Archetype } 3 \text { : mutually exclusive } \\
\text { interests }\end{array}$ & $\begin{array}{l}\text { Disagreements and contrary opinions } \\
\text { about land-use elements and provided } \\
\text { ecosystem services. }\end{array}$ & $\begin{array}{l}\text { Diversity in interests. This } \\
\text { archetype delivers a basis for } \\
\text { discussion in further steps of } \\
\text { archetype analysis. }\end{array}$ & $\begin{array}{l}\text { Disagreements are mainly individually } \\
\text { rooted. }\end{array}$ \\
\hline
\end{tabular}

\section{Archetype 3: mutually exclusive interests}

The stakeholders disagreed or held contrary opinions mainly on regulating services (Fig. 2). The stakeholders held contrary opinions on the relevance of intensively used grasslands, extensively used grasslands, extensively used wetlands, hedges, and mudflats to prevent erosion; the benefit of peat areas to water supply; and the relevance of salt marshes for freshwater retention and soil fertility. Additionally, the relevance of dikes for water supply was an issue that produced contrary opinions. Some stakeholders adhered to the opinion that freshwater would become brackish without dikes (landward protection function of the dike), whereas others noted that dike structures themselves do not provide freshwater supply.

Based on the distances in the NMDS (Fig. 4), disagreements and contrary opinions were mainly individual, rather than sector specific. For instance, the attributions made by the stakeholders from both the policy sector $(\mathrm{P})$ and the water management sector (W) differed strongly, whereas all nature conservationists $(\mathrm{N})$ had similar opinions. Within the agricultural sector (A), the evaluations of the farmers' association director (A1) and the head of the chamber of agriculture (A3) were similar, whereas the local farmer (A2) differed in his evaluations. Similarly, evaluations made by the engineer of the water board (W1) diverged from those of the director of the water board (W2) and the director of the dike board (W3).

\section{DISCUSSION}

\section{Cognitive archetypes}

Several attributions identify well-established and traditionally anchored elements within the existing landscape, e.g., grassland/ forage production, open water/freshwater supply, or arable fields/ food production. These attributions occur throughout the world and can be considered globally relevant archetypes (Václavík et al. 2013). Others, such as dikes/prevention of saltwater intrusion, salt marshes/wave attenuation, or reed stands/carbon sequestration, represent regional archetypes that are characteristic for the northwestern European coastal lowlands.

Archetype 1 describes monofunctional attributions that are often self-evident linkages between land-use elements and single ecosystem services. In our investigation, land-use elements with a monofunctional relationship to ecosystem services were either sites with strong sectoral use, i.e., agricultural with respect to bioenergy and nature conservation with respect to wetlands, or sites that might be relevant in the future, i.e., polder areas.

Fig. 4. Nonmetric multidimensional scaling plot of the distances between stakeholders regarding the similarity of their evaluations. Short distances represent similar evaluations. Only those attributions of land use and ecosystem services with disagreements or contrary opinions were taken into account (see Fig. 3). Water management (W1, engineer; W2, director, water board; W3, director, dike board), agriculture (A1, director, farmers' association; A2, head of department, chamber of agriculture; A3, farmer), nature conservation (N1, head of department, national park; N2, head of department, biosphere reserve), policy (P1, mayor; P2, head of department, spatial planning; P3, head of department, administrative office), and tourism (T1, director, tourism association).

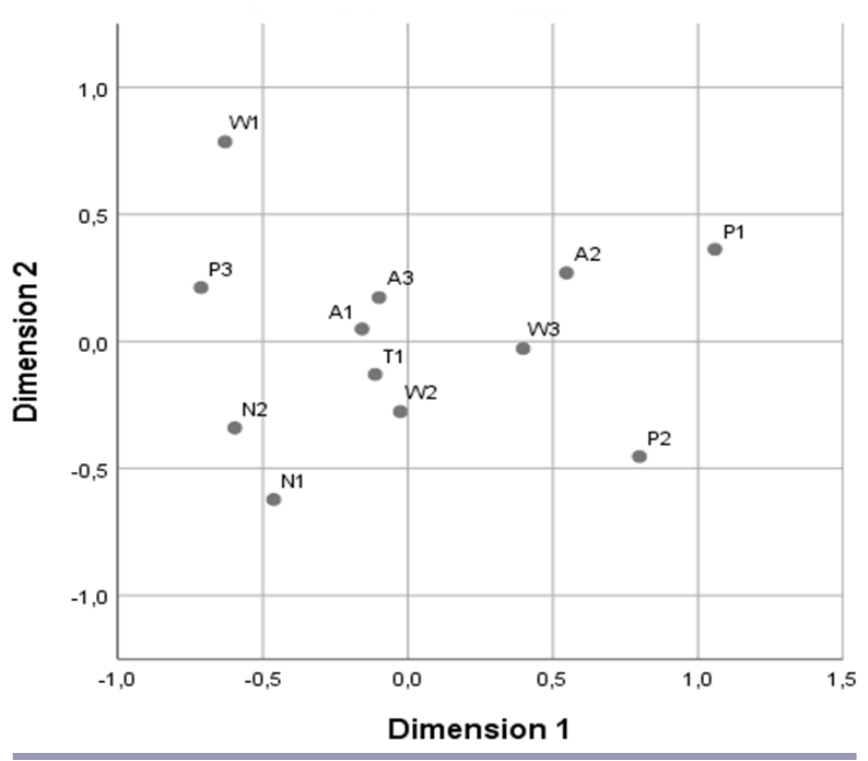

Archetype 2 describes multifunctional attributions and, therefore, land-use elements providing bundles of ecosystem services. This indicates interactions between different services that are important for the stakeholders, independent of a specific sector and related land-use interests. The identification of spatially co- 
occurring ecosystem services points to the multifunctionality of landscapes and balances the provision of different services. According to Queiroz et al. (2015), the identification of such bundles implies benefits for future land-use management by both increasing desired effects of multiple ecosystem services and recognizing possible trade-offs. These are provisioning services, like food, fodder, or energy, that are easily comprehensible by the stakeholders because they represent goods that can be traded or consumed (Dale and Polasky 2007, Kandziora et al. 2013). Additionally, the stakeholders mostly agreed on cultural ecosystem services. Investigations by Peña et al. (2015) and Döring and Ratter (2018) show that land-use management is the main contributor to the perceived aesthetic quality of a region and determines the social demand of cultural services. Because the case study area is highly modified by land reclamation, water drainage, and agriculture, many land-use elements (in total 14) are the basis for at least 1 cultural service. The stakeholders attributed recreation and tourism to almost half of all land-use elements. Similar results have been found by Koschke et al. (2012). In their study, stakeholders prioritized recreation and tourism over other services.

Examples of trade-offs (Rodríguez et al. 2006, Queiroz et al. 2015) among ecosystem services are the services soil fertility and production of food and forage provided by arable fields, meadows, and pastures. The stakeholders considered soil fertility necessary for food and forage production, but an increase of the provisioning services may lead to a decrease in soil fertility because of the increased use of fertilizer or pesticides (Fixen et al. 2015, Kaur et al. 2017).

Additional trade-offs arise from spatial mismatches. For instance, the increase of water retention areas and associated reed stands that enable carbon sequestration (Witte and Giani 2016) or an increase in extensively used wetlands promoting biodiversity will lead to a spatial decrease of arable land with food and forage production. In contrast to the studies carried out by RaudseppHearne et al. (2010) and van der Biest et al. (2014), our investigation does not clearly show actual spatial trade-offs between provisioning (food, forage, energy, and water supply) and regulating (hazard and climate regulation) services. A possible explanation is that land uses in such coastal lowlands are adapted to wet and flood-prone conditions over a long period of time. For instance, increasing the number and extension of rivers, creeks, ditches, and open waters would contribute to freshwater provision and retention and promote tourism and recreational activities as well. This is not necessarily a trade-off with food or forage production, because drainage and discharge of excess rain water are necessary to maintain the agricultural productivity of coastal lowlands.

We have identified cognitive archetypes in stakeholder-based attributions of land-use elements and perceived outputs of ecosystem services. Most land-use elements are multifunctional and support synergistic bundles of ecosystem services (archetype 2; Potschin and Haines-Young 2006, Raudsepp-Hearne et al. 2010, Van der Biest et al. 2014). Stakeholders disagree on twothirds of attributions, showing that archetypes 1 and 2 are limited mainly to provisioning and cultural services and that archetype 3 is based on individual perceptions.

Archetype 3 describes disagreements and contrary opinions on attributions and shows that these attributions are mainly individual and not associated with the sectors the stakeholders represented (Fig. 4). This indicates that individual knowledge of service outputs of multiple land-use elements differed strongly among the stakeholders, particularly regarding regulating services. This is in line with studies by Carpenter et al. (2006), Primmer and Furman (2012), and Kandziora et al. (2013), explaining that stakeholders do not widely recognize regulating services within their environment. A glossary with a commonly elaborated list of definitions was provided in an attempt to avoid confusion, but subjective perceptions cannot be excluded in a participatory process, because values and meanings concerning land-use elements and ecosystem services differ depending on the stakeholders' backgrounds (Plieninger et al. 2015). For instance, the stakeholders disagreed on the relevance of buildings for forage and energy production as well as water supply. One explanation is that some stakeholders did not see any relevance because buildings do not produce these services. Others stakeholders argued that buildings are relevant as, e.g., cattle sheds, barns for forage storage, or infrastructure for energy and water supply. Disagreements also included land-use elements currently not represented or underrepresented in the landscape, such as polder areas, which showed the highest number of disagreements; peat areas; trees; or hedges. Apparently, stakeholders had difficulty attributing ecosystem services to land-use elements that they only seldom encountered in their landscape. We included such landuse elements in our investigation to raise the stakeholders' awareness regarding potential future benefits of such areas. One example is to use polder areas to store freshwater in times of extreme events and strengthen services such as freshwater supply, rapid water drainage, freshwater retention, and biodiversity (Karrasch et al. 2017).

Sector-specific disagreements and contrary opinions reflected mutually exclusive interests of the stakeholders, such as farmers and nature conservationists. For example, the farmers were convinced that all agricultural land-use elements contributed to high biodiversity of, e.g., plants and birds (Cebrián-Piqueras et al. 2017a). The nature conservationists opined that intensively used agricultural areas have comparatively low value in terms of biodiversity. As reviewed in Seppelt et al. (2016), intensification of agricultural activities has a negative impact on biodiversity, whereas biodiversity can have positive impacts on agricultural production, because it strengthens ecosystem functions.

Even though mutually exclusive interests (archetype 3) were mainly not sector specific, it is conspicuous that the representatives of the policy sector had very different understandings of the capacity of land-use elements to provide ecosystem services, both among themselves and in comparison with stakeholders from other societal sectors. Additionally, it is interesting that stakeholders belonging to the same administrative level, e.g., directors of water management, agriculture, and tourism sectors, evaluated attributions in similar ways, whereas practitioners had very different opinions. One possible explanation is that stakeholders acting on a higher level of formal decision making are exposed to more diverse fields of community and regional planning. In contrast, stakeholders of specific public services, such as farmers, water managers, or nature conservationists, may relate more to services provided by landuse elements associated with their individual activities, such as fields or watercourses. This indicates that people "working in the field" may have another perception of the capacity of land uses 
to provide ecosystem services. The different levels, i.e., administrative or practitioner, of dependency can be considered one reason why the ecosystem-based management approach in formal planning is still in its infancy (Wamsler 2015).

In contrast to archetypes 1 and 2, which provide clear stakeholders' perceptions and consensus of land use and ecosystem service outputs, the analysis of disagreements and contrary opinions delivers the basis for discussion in further planning processes. To reach congruence between subjective and objective dynamics of systems, it is important to include sociocultural processes and couple these processes with natural dynamics (Manuel-Navarrete 2015). Land-use planning and management including ecosystem services can be discussed and elaborated either by generating knowledge or by pointing out issues of conflict in land use. By explaining the reasons for disagreements, consensus-building processes can be stimulated and new knowledge generated.

\section{Outlook phase 2: archetypes to develop ecosystem-based land management options}

Cognitive archetypes based on stakeholders' perceptions of landuse element-ecosystem service attributions bring local context and societal demands to evaluation processes. They could be considered as the first step in initiating ecosystem-based action. According to Eisenack (2012), archetypes build spatial representative patterns of society-nature interactions and their complex relationships. These relationships are addressed by cognitive archetypes, which can contribute to raise stakeholders' awareness of society-nature interactions, especially with regard to the benefits they obtain from ecosystems and dependencies between land use and services provided. These building blocks can be used in the second phase of archetype analysis to establish connections between regions and guide cross-sectoral decisionmaking processes defining future ecosystem-based land management options. For example, the archetypes laid the foundation of scenario development, showing possible future land management and spatial planning intervention options. The results of our investigation have already been used to design and evaluate different land management options for a sustainable climate adaptation strategy for the case study region (Karrasch et al. 2017). Positioning land-use elements in relation to the provision of ecosystem services made it possible for the stakeholders to understand and evaluate ecosystem services. A good understanding of ecosystem services and the attribution to land-use elements is essential to grasp the relationships between natural capital, societal demands, and human well-being (Fish 2011, Maes et al. 2012, Fedele et al. 2018).

The detection of archetypical attributions paves the way for noncontroversial decisions in land management, may facilitate landscape planning, and tailors the provision of ecosystem services to societal demands (Stürck and Verburg 2017). To further avoid land-use conflicts, the establishment of mosaic landscapes combining different land uses on a small scale may strengthen the provision of (bundles of) ecosystem services in the coastal region. This might become important for the future development of the region, because ecosystem-based management and the development of multifunctional areas to reduce competition over space and resources will be necessary to ensure well-being and adaptation to impacts of climate change
(Brandt and Vejre 2004, Queiroz et al. 2015). By deploying archetypes of the attributions outlined previously as building blocks for future land-use management, our results may be transferable to other regions with similar environmental and societal conditions (for examples, see Václavík et al. 2016).

\section{CONCLUSION}

We emphasize stakeholders' viewpoints and open up a new approach to define and develop cognitive archetypes in planning practice. Although spatial archetypes have to date usually been identified on the basis of statistical geodata (e.g., Václavík et al. 2013), we started with a participatory determination of land-use elements and ecosystem services that stakeholders consider in their management practices. Taking regional stakeholders' perceptions and evaluations into account, we propose deploying cognitive archetypes as attributions of land-use elements and their ecosystem service outputs in the context of land-use management patterns. Agreements in land-use element-ecosystem service attributions present both regionally specific and globally important archetypes. These findings underpin that cognitive archetypes can be used to understand the general dynamics of social-ecological systems and to deliver information for future land-use management (Eisenack 2012).

Based on these land-use element-ecosystem service attributions and the comparison of 12 different cases, we identified 3 archetypes. Two archetypes address agreements among stakeholders with diverse interests and from diverse socioeconomic sectors. The agreements can be monofunctional (archetype 1), if one land-use element is relevant for the provision of a certain ecosystem service. Agreements can also indicate multifunctionality (archetype 2), if one land-use element is relevant for bundles of ecosystem services. However, if no consensus on the ecosystem service outputs of certain land-use elements is achieved among the participants, assessments may become inconsistent or even impossible. Such mainly idiosyncratic and individually rooted disagreements point to the necessity to promote a common knowledge and understanding of the ecosystem processes underlying the provision of regulating services.

The inclusion of multiple stakeholder perspectives has the potential to trigger the process of discussing and finding integrated solutions to the next steps of ecosystem-based management activities. Cognitive archetypes as we have described merit consideration as policy-relevant patterns for future landuse options. Trade-offs and disagreements enable stakeholders to identify gaps and communicate information on sustainable and ecosystem-based land management.

Responses to this article can be read online at: http://www.ecologyandsociety.org/issues/responses. $\mathrm{php} / 10744$

\section{Acknowledgments:}

The authors would like to thank the stakeholders who took an active part in our study. Their insights and knowledge were invaluable for our research. Our special thanks go to Marcel Kuhmann for his 
contributions to the statistical analysis. This project was part of the collaborative research project "Sustainable coastal land management: trade-offs in ecosystem services" (COMTESS), supported by the German Federal Ministry of Education and Research (grant number 01LL0911).

\section{LITERATURE CITED}

Agarwal, S., J. Wills, L. Cayton, G. Lanckriet, D. Kriegman, and S. Belongie. 2007. Generalized non-metric multidimensional scaling. Proceedings of Machine Learning Research 2:11-18.

Albert, C., J. Aronson, C. Fürst, and P. Opdam. 2014. Integrating ecosystem services in landscape planning: requirements, approaches, and impacts. Landscape Ecology 29(8):1277-1285. https://doi.org/10.1007/s10980-014-0085-0

Bossard, M., J. Feranec, and J. Otahel. 2000. CORINE land cover technical guide - addendum 2000. Technical Report No. 40. European Environment Agency, Copenhagen, Denmark.

Brandt, J., and H. Vejre. 2004. Multifunctional landscapes motives, concepts and perspectives. Pages 3-32 in J. Brandt and H. Vejre, editors. Multifunctional landscapes. Volume 1, theory, values and history. WIT Press, Southampton, UK.

Burkhard, B., F. Kroll, F. Müller, and W. Windhorst. 2009. Landscapes' capacities to provide ecosystem services - a concept for land-cover based assessments. Landscape Online 15:1-22. https://doi.org/10.3097/LO.200915

Carpenter, S. R., R. DeFries, T. Dietz, H. A. Mooney, S. Polasky, W. V. Reid, and R. J. Scholes. 2006. Millennium Ecosystem Assessment: research needs. Science 314:257-258. https://doi. org/10.1126/science. 1131946

Cebrián-Piqueras, M. A., L. Karrasch, and M. Kleyer. $2017 a$. Coupling stakeholder assessments of ecosystem services with biophysical ecosystem properties reveals importance of social contexts. Ecosystem Services 23:108-115. https://doi.org/10.1016/ j.ecoser.2016.11.009

Cebrián-Piqueras, M. A., J. Trinogga, C. Grande, V. Minden, M. Maier, and M. Kleyer. 2017b. Interactions between ecosystem properties and land use clarify spatial strategies to optimize tradeoffs between agriculture and species conservation. International Journal of Biodiversity Science, Ecosystem Services and Management 13(2):53-66.

Council of the European Union. 1992. Council directive 92/43/ EEC of 21 May 1992 on the conservation of natural habitats and of wild fauna and flora. Official Journal of the European Union L 206:7-50.

Cullum, C., G. Brierley, G. L. W. Perry, and E. T. F. Witkowski. 2017. Landscape archetypes for ecological classification and mapping: the virtue of vagueness. Progress in Physical Geography: Earth and Environment 41(1):95-123. https://doi. org/10.1177/0309133316671103

Daily, G. C., and P. A. Matson. 2008. Ecosystem services: from theory to implementation. Proceedings of the National Academy of Sciences of the United States of America 105(28):9455-9456. https://doi.org/10.1073/pnas.0804960105
Dale, V. H., and S. Polasky. 2007. Measures of the effects of agricultural practices on ecosystem services. Ecological Economics 64(2):286-296. https://doi.org/10.1016/j.ecolecon.2007.05.009

de Groot, R. S., R. Alkemade, L. Braat, L. Hein, and L. Willemen. 2010. Challenges in integrating the concept of ecosystem services and values in landscape planning, management and decision making. Ecological Complexity 7(3):260-272. https://doi. org/10.1016/j.ecocom.2009.10.006

Döring, M., and B. M. W. Ratter. 2018. Coastal landscapes: the relevance of researching coastscapes for managing coastal change in North Frisia. Area 50(2):169-176. https://doi.org/10.1111/ area. 12382

Dunford, R., P. Harrison, A. Smith, J. Dick, D. N. Barton, B. Martin-Lopez, E. Kelemen, S. Jacobs, H. Saarikoski, F. Turkelboom, W. Verheyden, J. Hauck, P. Antunes, R. Aszalós, O. Badea, F. Baró, P. Berry, L. Carvalho, G. Conte, B. Czúcz, G. Garcia Blanco, D. Howard, R. Giuca, E. Gomez-Baggethun, B. Grizzetti, Z. Izakovicova, L. Kopperoinen, J. Langemeyer, S. Luque, D. M. Lapola, G. Martinez-Pastur, R. Mukhopadhyay, S. B. Roy, J. Niemelä, L. Norton, J. Ochieng, D. Odee, I. Palomo, P. Pinho, J. Priess, G. Rusch, S.-R. Saarela, R. Santos, J. T. van der Wal, A. Vadineanu, Á. Vári, H. Woods, and V. Yli-Pelkonen. 2018. Integrating methods for ecosystem service assessment: experiences from real world situations. Ecosystem Services 29 (C):499-514. https://doi.org/10.1016/j.ecoser.2017.10.014

Eisenack, K. 2012. Archetypes of adaptation to climate change. Pages 107-122 in Glaser M., G. Krause, B. Ratter, and M. Welp, editors. Human-nature interactions in the Anthropocene: potentials of social-ecological systems analysis. Routledge, New York, New York, USA.

Eisenack, K., A. Gotgelf, U. Kasymov, P. Lutz, P. Perez, C. Oberlack, and D. Sietz. 2018. Second research workshop on archetype analysis in sustainability research. Workshop report. Humboldt Universität zu Berlin, Berlin, Germany.

European Parliament, Council of the European Union. 2010. Directive 2009/147/EC of the European Parliament and of the Council of 30 November 2009 on the conservation of wild birds. Official Journal of the European Union L 20:7-25.

Fedele, G., B. Locatelli, H. Djoudi, and M. J. Colloff. 2018. Reducing risks by transforming landscapes: cross-scale effects of land-use changes on ecosystem services. PLoS ONE 13(4): e0195895. https://doi.org/10.1371/journal.pone.0195895

Fish, R. D. 2011. Environmental decision making and an ecosystems approach: some challenges from the perspective of social science. Progress in Physical Geography: Earth and Environment 35(5):671-680. https://doi.org/10.1177/0309133311420941

Fixen, P., F. Brentrup, T. Bruulsema, F. Garcia, R. Norton, and S. Zingore. 2015. Nutrient/fertilizer use efficiency: measurement, current situation and trends. Pages 8-37 in P. Drechsel, P. Heffer, H. Magen, R. Mikkelsen, and D. Wichelns, editors. Managing water and fertilizer for sustainable agricultural intensification. First edition. International Fertilizer Industry Association, International Water Management Institute, International Plant Nutrition Institute, and International Potash Institute, Paris, France. 
Fürst, C., S. Luque, and D. Geneletti. 2017. Nexus thinking-how ecosystem services can contribute to enhancing the cross-scale and cross-sectoral coherence between land use, spatial planning and policy-making. International Journal of Biodiversity Science, Ecosystem Services and Management 13(1):412-421. https://doi. org/10.1080/21513732.2017.1396257

Kandziora, M., B. Burkhard, and F. Müller. 2013. Interactions of ecosystem properties, ecosystem integrity and ecosystem service indicators - a theoretical matrix exercise. Ecological Indicators 28:54-78. https://doi.org/10.1016/j.ecolind.2012.09.006

Karrasch, L. 2016. Matching an ecosystem services approach with social impact assessment. Pages 86-112 in D. Geneletti, editor. Handbook on biodiversity and ecosystem services in impact assessment. Edward Elgar, Cheltenham, UK. https://doi. org/10.4337/9781783478996.00010

Karrasch, L., M. Maier, M. Kleyer, and T. Klenke. 2017. Collaborative landscape planning: co-design of ecosystem-based land management scenarios. Sustainability 9(9):1668. https://doi. org/10.3390/su9091668

Kaur, S., V. Kumar, M. Chawla, L. Cavallo, A. Poater, and N. Upadhyay. 2017. Pesticides curbing soil fertility: effect of complexation of free metal ions. Frontiers in Chemistry 5:43. https://doi.org/10.3389/fchem.2017.00043

Koschke, L., C. Fürst, S. Frank, and F. Makeschin. 2012. A multicriteria approach for an integrated land-cover-based assessment of ecosystem services provision to support landscape planning. Ecological Indicators 21:54-66. https://doi.org/10.1016/j. ecolind.2011.12.010

Langerwisch, F., T. Václavík, W. von Bloh, T. Vetter, and K. Thonicke. 2018. Combined effects of climate and land-use change on the provision of ecosystem services in rice agro-ecosystems. Environmental Research Letters 13(1):015003. https://doi. org/10.1088/1748-9326/aa954d

Lavorel, S., K. Grigulis, G. Leitinger, M. Kohler, U. Schirpke, and U. Tappeiner. 2017. Historical trajectories in land use pattern and grassland ecosystem services in two European alpine landscapes. Regional Environmental Change 17(8):2251-2264. https://doi. org/10.1007/s10113-017-1207-4

Levers, C., D. Müller, K. Erb, H. Haberl, M. R. Jepsen, M. J. Metzger, P. Meyfroidt, T. Plieninger, C. Plutzar, J. Stürck, P. H. Verburg, P. J. Verkerk, and T. Kuemmerle. 2018. Archetypical patterns and trajectories of land systems in Europe. Regional Environmental Change 18(3):715-732. https://doi.org/10.1007/ s10113-015-0907-x

Lim-Camacho, L., A. Ariyawardana, G. K. Lewis, S. J. Crimp, S. Somogyi, B. Ridoutt, and S. M. Howden. 2017. Climate adaptation of food value chains: the implications of varying consumer acceptance. Regional Environmental Change 17 (1):93-103. https://doi.org/10.1007/s10113-016-0976-5

Maes, J., B. Egoh, L. Willemen, C. Liquete, P. Vihervaara, J. P. Schägner, B. Grizzetti, E. G. Drakou, A. L. Notte, G. Zulian, F. Bouraoui, M. Luisa Paracchini, L. Braat, and G. Bidoglio. 2012. Mapping ecosystem services for policy support and decision making in the European Union. Ecosystem Services 1(1):31-39. https://doi.org/10.1016/j.ecoser.2012.06.004
Manuel-Navarrete, D. 2015. Double coupling: modeling subjectivity and asymmetric organization in social-ecological systems. Ecology and Society 20(3):26. https://doi.org/10.5751/ ES-07720-200326

Millennium Ecosystem Assessment. 2003. Ecosystems and human well-being: a framework for assessment. Island, Washington, D. C., USA.

Müller, F., and B. Burkhard. 2012. The indicator side of ecosystem services. Ecosystem Services 1(1):26-30. https://doi.org/10.1016/j. ecoser.2012.06.001

Müller, F., R. de Groot, and L. Willemen. 2010. Ecosystem services at the landscape scale: the need for integrative approaches. Landscape Online 23:1-11. https://doi.org/10.3097/LO.201023

Oberlack, C., and K. Eisenack. 2014. Alleviating barriers to urban climate change adaptation through international cooperation. Global Environmental Change 24:349-362. https://doi.org/10.1016/ j.gloenvcha.2013.08.016

Oberlack, C., L. Tejada, P. Messerli, S. Rist, and M. Giger. 2016. Sustainable livelihoods in the global land rush? Archetypes of livelihood vulnerability and sustainability potentials. Global Environmental Change 41:153-171. https://doi.org/10.1016/j. gloenvcha.2016.10.001

Opdam, P. 2013. Using ecosystem services in community-based landscape planning: science is not ready to deliver. Pages 77-101 in B. Fu and K. B. Jones, editors. Landscape ecology for sustainable environment and culture. Springer, Dordrecht, The Netherlands. https://doi.org/10.1007/978-94-007-6530-6_5

Peña, L., I. Casado-Arzuaga, and M. Onaindia. 2015. Mapping recreation supply and demand using an ecological and a social evaluation approach. Ecosystem Services 13:108-118. https://doi. org/10.1016/j.ecoser.2014.12.008

Plieninger, T., T. Kizos, C. Bieling, L. Le Dû-Blayo, M.-A. Budniok, M. Bürgi, C. L. Crumley, G. Girod, P. Howard, J. Kolen, T. Kuemmerle, G. Milcinski, H. Palang, K. Trommler, and P. H. Verburg. 2015. Exploring ecosystem-change and society through a landscape lens: recent progress in European landscape research. Ecology and Society 20(2):5. https://doi.org/10.5751/ES-07443-200205

Potschin, M. B., and R. H. Haines-Young. 2006. Landscapes and sustainability. Landscape and Urban Planning 75(3-4):155-161. https://doi.org/10.1016/j.landurbplan.2005.03.006

Potschin, M., and R. Haines-Young. 2013. Landscapes, sustainability and the place-based analysis of ecosystem services. Landscape Ecology 28(6):1053-1065. https://doi.org/10.1007/ s10980-012-9756-X

Primmer, E., and E. Furman. 2012. Operationalising ecosystem service approaches for governance: do measuring, mapping and valuing integrate sector-specific knowledge systems? Ecosystem Services 1(1):85-92. https://doi.org/10.1016/j.ecoser.2012.07.008

Queiroz, C., M. Meacham, K. Richter, A. V. Norström, E. Andersson, J. Norberg, and G. Peterson. 2015. Mapping bundles of ecosystem services reveals distinct types of multifunctionality within a Swedish landscape. $A M B I O 44(\mathrm{~S} 1): 89-101$. https://doi. org/10.1007/s13280-014-0601-0 
Raudsepp-Hearne, C., G. D. Peterson, and E. Bennett. 2010. Ecosystem service bundles for analyzing tradeoffs in diverse landscapes. Proceedings of the National Academy of Sciences of the United States of America 107(11):5242-5247. https://doi. org/10.1073/pnas.0907284107

Rauken, T., P. K. Mydske, and M. Winsvold. 2015. Mainstreaming climate change adaptation at the local level. Local Environment 20(4):408-423. https://doi.org/10.1080/13549839.2014.880412

Reise, K. 2005. Coast of change: habitat loss and transformations in the Wadden Sea. Helgoland Marine Research 59(1):9-21. https://doi.org/10.1007/s10152-004-0202-6

Rodríguez, J. P., T. D. Beard, Jr., E. M. Bennett, G. S. Cumming, S. Cork, J. Agard, A. P. Dobson, and G. D. Peterson. 2006. Tradeoffs across space, time, and ecosystem services. Ecology and Society 11(1):28. https://doi.org/10.5751/ES-01667-110128

Schleyer, C., C. Görg, J. Hauck, and K. J. Winkler. 2015. Opportunities and challenges for mainstreaming the ecosystem services concept in the multi-level policy-making within the EU. Ecosystem Services 16:174-181. https://doi.org/10.1016/j. ecoser.2015.10.014

Schultz, L., C. Folke, H. Österblom, and P. Olsson. 2015. Adaptive governance, ecosystem management, and natural capital. Proceedings of the National Academy of Sciences of the United States of America 112(24):7369-7374. https://doi.org/10.1073/ pnas. 1406493112

Seppelt, R., M. Beckmann, S. Ceauşu, A. F. Cord, K. Gerstner, J. Gurevitch, S. Kambach, S. Klotz, C. Mendenhall, H. R. P. Phillips, K. Powell, P. H. Verburg, W. Verhagen, M. Winter, and T. Newbold. 2016. Harmonizing biodiversity conservation and productivity in the context of increasing demands on landscapes. BioScience 66(10):890-896. https://doi.org/10.1093/biosci/biw004

Sietz, D., S. E. M. Choque, and M. K. B. Lüdeke. 2012. Typical patterns of smallholder vulnerability to weather extremes with regard to food security in the Peruvian Altiplano. Regional Environmental Change 12(3):489-505. https://doi.org/10.1007/ $\underline{\text { s10113-011-0246-5 }}$

Sietz, D., J. C. Ordoñez, M. T. J. Kok, P. Janssen, H. B. M. Hilderink, P. Tittonell, and H. van Dijk. 2017. Nested archetypes of vulnerability in African drylands: where lies potential for sustainable agricultural intensification? Environmental Research Letters 12(9):095006. https://doi.org/10.1088/1748-9326/aa768b

Simpson, E. H. 1949. Measurement of diversity. Nature 163 (4148):688. https://doi.org/10.1038/163688a0

Stürck, J., and P. H. Verburg. 2017. Multifunctionality at what scale? A landscape multifunctionality assessment for the European Union under conditions of land use change. Landscape Ecology 32(3):481-500. https://doi.org/10.1007/s10980-016-0459-6

UK National Assessment. 2011. The UK National Ecosystem Assessment: synthesis of the key findings. United Nations Environment Programme, World Conservation Monitoring Centre, Cambridge, UK.

Václavík, T., F. Langerwisch, M. Cotter, J. Fick, I. Häuser, S. Hotes, J. Kamp, J. Settele, J. H. Spangenberg, and R. Seppelt. 2016. Investigating potential transferability of place-based research in land system science. Environmental Research Letters 11(9):095002. https://doi.org/10.1088/1748-9326/11/9/095002

Václavík, T., S. Lautenbach, T. Kuemmerle, and R. Seppelt. 2013. Mapping global land system archetypes. Global Environmental Change 23(6):1637-1647. https://doi.org/10.1016/j.gloenvcha.2013.09.004

Van der Biest, K., R. D’Hondt, S. Jacobs, D. Landuyt, J. Staes, P. Goethals, and P. Meire. 2014. EBI: an index for delivery of ecosystem service bundles. Ecological Indicators 37A:252-265. https://doi.org/10.1016/j.ecolind.2013.04.006

Verhagen, W., A. J. A. van Teeffelen, A. B. Compagnucci, L. Poggio, A. Gimona, and P. H. Verburg. 2016. Effects of landscape configuration on mapping ecosystem service capacity: a review of evidence and a case study in Scotland. Landscape Ecology 31 (7):1457-1479. https://doi.org/10.1007/s10980-016-0345-2

Verhagen, W., A. J. A. van Teeffelen, and P. H. Verburg. 2018. Shifting spatial priorities for ecosystem services in Europe following land use change. Ecological Indicators 89:397-410. https://doi.org/10.1016/j.ecolind.2018.01.019

Vidal Merino, M., D. Sietz, F. Jost, and U. Berger. 2018. Archetypes of climate vulnerability: a mixed-method approach applied in the Peruvian Andes. Climate and Development, in press. https://doi.org/10.1080/17565529.2018.1442804

Vrebos, D., J. Staes, T. Vandenbroucke, T. D'Haeyer, R. Johnston, M. Muhumuza, C. Kasabeke, and P. Meire. 2015. Mapping ecosystem service flows with land cover scoring maps for datascarce regions. Ecosystem Services 13:28-40. https://doi. org/10.1016/j.ecoser.2014.11.005

Wamsler, C. 2015. Mainstreaming ecosystem-based adaptation: transformation toward sustainability in urban governance and planning. Ecology and Society 20(2):30. https://doi.org/10.5751/ ES-07489-200230

Wardropper, C. B., S. Gillon, A. S. Mase, E. A. McKinney, S. R. Carpenter, and A. R. Rissman. 2016. Local perspectives and global archetypes in scenario development. Ecology and Society 21(2):12. https://doi.org/10.5751/ES-08384-210212

Witte, S., and L. Giani. 2016. Greenhouse gas emission and balance of marshes at the southern North Sea coast. Wetlands 36 (1):121-132. https://doi.org/10.1007/s13157-015-0722-7 